\title{
Source identification of VOCs in METU Campus through factor analysis
}

\author{
Uzunpınar E.S. ${ }^{1 *}$, Ezgi Sert E. ${ }^{1}$, Aslan Kılavuz S. ${ }^{2}$, İpek İmamoğlu I. ${ }^{1}$ and Tuncel G. ${ }^{1}$ \\ ${ }^{1}$ Department of Environmental Engineering, Middle East Technical University, 06800, Ankara, Turkey \\ ${ }^{2}$ Department of Environmental Engineering, Kocaeli University, 41380, Kocaeli, Turkey \\ Received: 25/05/2017, Accepted: 25/08/2017, Available online: 24/01/2018 \\ *to whom all correspondence should be addressed: e-mail: sena@metu.edu.tr
}

\begin{abstract}
In this study, 51 ozone precursor VOCs, which are routinely measured in PAMS (Photochemical Assessment Monitoring Station) were measured in a suburban station located at Middle East Technical University, Environmental Engineering Department in, Ankara. Daily air samples were collected in evacuated canisters between January December, 2014. Collected samples were analyzed with GC-FID system and concentrations of 51 VOCs were determined. Mean VOC concentrations ranged between $0.048 \pm 0.061 \mu \mathrm{g} \mathrm{m}^{-3}$ (cis-2-penten) and $10 \pm 13 \mu \mathrm{g} \mathrm{m}-3$ (toluene). Average benzene concentration was $1.49 \pm 1.74$ $\mu \mathrm{g} \mathrm{m}^{-3}$. Factor Analysis (FA) was applied to determine the major sources of VOCs that contribute to the measured concentrations in the university campus. FA application revealed nine factors that can be grouped under four major components, including (1) transportation: gasoline vehicle exhaust emissions, evaporative losses from gasoline vehicles, gasoline evaporation in gas stations and diesel emissions, (2) industrial emissions: industrial evaporation and industrial application, (3) solvent emissions: surface coatings and solvent use and (4) asphalt application.
\end{abstract}

Keywords: Canister, Source Apportionment

\section{Introduction}

Air pollution is defined as the contamination of indoor and outdoor environments through the alteration of the natural composition of the atmosphere with the addition of various factors in it (WHO, 2015). These factors can include physical, chemical and biological agents of any kind. Volatile organic compounds (VOCs) are one of the important subgroups of chemical contaminants that cause air pollution.

VOCs can be defined differently, such as reactive organic gases (ROG), non-methane organic compounds (NMOC) or photochemical assessment monitoring stations (PAMS) etc., depending on the chemical composition of the species. As a more general definition for VOCs, definition provided by U.S.EPA can be adopted. U.S.EPA defines VOCs as any compound containing carbon and that has a role in atmospheric photochemical reactions, except carbon monoxide, carbon dioxide, carbonic acid, metallic carbides or carbonates, and ammonium carbonate (U.S.EPA, 2009). A more detailed definition is given in U.S.EPA Method TO15 as "organic compounds having a vapor pressure greater than $10^{-1}$ Torr at $25^{\circ} \mathrm{C}$ and $760 \mathrm{~mm} \mathrm{Hg}$ " (U.S.EPA, 1999).

VOC sources are as diverse as the compounds they include. Sources that contribute to the VOC emissions in the atmosphere can be grouped into two categories as biogenic (Atkinson and Arey, 2003; Williams and Koppmann, 2007; Zemankova and Brechler, 2010) and anthropogenic sources such as traffic emission (Han and Naeher, 2006), petroleum evaporation and petroleum emission (Kountouriotis et al., 2014) and industrial processes and diesel motor vehicles (Williams \& Koppmann, 2007). According to Emission Database for Global Atmospheric Research (EDGAR), in 2008, 0.16 Gtonnes of NMVOC were released in to the atmosphere from anthropogenic sources (EDGAR, 2011) whereas biogenic sources emit ten times more VOC emissions compared to anthropogenic sources (Atkinson and Arey, 2003).

Due to their excessive amounts of emissions and possible effects on humans (e.g. cancer, asthma), vegetation (e.g. growth inhibition) and the atmospheric processes (e.g. ground level ozone formation), identification of sources of VOCs and their contribution to emissions is very important.

In this study, fifty-one EPA Photochemical Assessment Monitoring Stations (PAMS) target VOCs were used as tracers for the apportionment of the sources in Ankara atmosphere. The discussion in this paper focuses on the application of factor analysis (FA) on VOC concentrations measured in suburban Ankara atmosphere between January, 2014 and December, 2014 for the determination of major sources that are contributing to the measured concentrations.

\section{Materials and Methods}

\subsection{Study Area}

Ankara, the capital city of Turkey, has the second highest population in Turkey with a population of 5,150,072 residents, according to the results of 2014 census (Turkish Statistical Institute, 2014). The city is located at $39.57 \mathrm{~N}$ latitude and $32.53 \mathrm{E}$ longitude, has a surface area of 
$26.897 \mathrm{~km}^{2}$ and is $890 \mathrm{~m}$ above sea level. Ankara is under the effect of continental climate and average temperature of the city is $11.9^{\circ} \mathrm{C}$ (MGM, 2014).

Middle East Technical University (METU) has one of the biggest campuses in Ankara and it is located in Cankaya district of Ankara. It has a campus area of $45 \mathrm{~km}^{2}$ without forests, and $75 \mathrm{~km}^{2}$ when forests included. It has a population of almost 40000 with students, academic and administrational personnel.

Sampling was conducted at the Department of Environmental Engineering in Middle East Technical University, Ankara (Figure 1-a). This site was chosen as a suburban sampling site due to its distance from main arteries. The sampling site is located $1.34 \mathrm{~km}$ west of the nearest road, Malazgirt Boulevard. Bilkent Boulevard is $1.59 \mathrm{~km}$ west and Eskişehir Highway is $2.36 \mathrm{~km}$ north of the sampling site (Figure 1-b).

\subsection{Sampling Campaign}

Samples were collected between January - December, 2014 as 24-hr daily samples with the use of stainless-steel canisters. 217 daily samples were collected at the end of the study period. Canister sampling was chosen over other methods, such as solid sorbents and tedlar bags, due to the advantages they provide in protection of sample integrity, collection of both heavy and light hydrocarbons, ability to perform replicate analysis and reduction in contamination problems (Wang and Austin, 2006).

Collected samples were analyzed with Agilent Model 6890 Gas Chromatography - Flame Ionization Detector (GC-FID). GC-FID analysis parameters were set according to the methodology developed by Kuntasal (2005) and (Yurdakul, 2014). Samples are collected for 25 minutes with $20 \mathrm{ml} / \mathrm{min}$ flow rate to obtain $500 \mathrm{ml}$ sample volume. Trap temperature starts at $-15{ }^{\circ} \mathrm{C}$ for the quantification of ethane and acetylene, (Yurdakul, 2014) rises to $300{ }^{\circ} \mathrm{C}$ and is held for 3 minutes. After cold trap, sample is injected to the system. Oven temperature starts at $40{ }^{\circ} \mathrm{C}$ and is held for 5.0 minutes. Then, the temperature starts to increase with a rate of $5{ }^{\circ} \mathrm{C} / \mathrm{min}$ until $195{ }^{\circ} \mathrm{C}$ and is held for 10.0 minutes. Analysis of a single sample lasts 46.0 minutes.

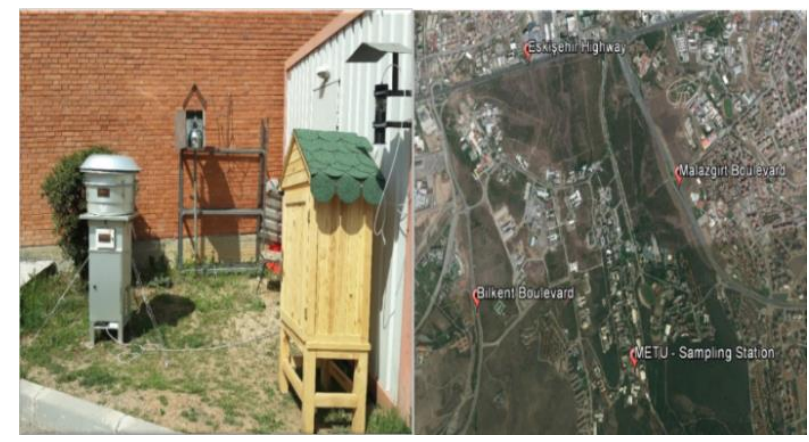

Figure 1. Sampling site (a) and its location (b)

\subsection{Factor Analysis}

Factor Analysis (FA) was run in two steps with the use of Factor Analysis property of STATGRAPHICS statistical software. In the first step, all VOCs with missing data $<20 \%$ were included in FA exercise. 220 samples and 41 VOCs were included in first run of FA. Compounds with below detection limit values were filled in with half of the detection limit of that particular VOC, whereas compounds with measurements less than blank values were replaced by half of the blank value of that VOC.

Seven factors with eigenvalues $>1.0$ were extracted after Varimax rotation. Eight VOCs (undecane, 1-pentene, oethyltoluene, methylcyclohexane, cis-2-butene, ethane, isoprene, 2,3-trimethylbenzene) were removed from the second FA run, because they had too small communalities. Forty-three samples with factor scores $>7.0$ (of any factor) were excluded from second run as very high scores have very strong impact on composition of factors. In this way, second FA run was performed with 177 samples and 33 VOCs. In the second FA run, nine factors with eigenvalues > 1.0 (Kaiser Criterion) (Civan et al., 2011; Liu et al., 2014; Rourke and Hatcher, 2013) were extracted after Varimax rotation.

\section{Results and Discussions}

\subsection{Descriptive Statistics of Collected Data}

The mean, median, minimum and maximum concentrations of measured VOCs are given in Table 1. Median concentrations ranged between $0.03-6.14 \mu \mathrm{g} \mathrm{m}^{-3}$ for cis-2-pentene and isobutene, whereas mean concentrations ranged between $0.04 \pm 0.06$ and $10.30 \pm 13.84$ for cis-2-pentene and toluene, respectively. Mean concentrations of VOCs were generally a factor of 2 higher than their median concentrations, which was due to right skewed distributions.

The GC was calibrated for 55 VOCs. Four of them were not detected in any of the samples and removed from our data set entirely. Forty-eight of the 51 remaining compounds were detected in $>50 \%$ of the samples. These are used in most of the statistical tests. Concentrations of the remaining three compounds that were detected in $<50 \%$ of our samples, namely Cis-2-pentene, 2,3,4trimethylpentane and 1,2,4-trimethylbenzene compounds (these were detected in $25 \%, 21 \%$ and $42 \%$ of the samples, respectively) were used in tables as they have information value, but not included in most of our statistical test.

Benzene is the only compound that has a standard value in Turkish Air Quality Regulation (5 $\mathrm{g} \mathrm{m} \mathrm{m}^{-3}$ ) (MoEU, 2008). Average and median benzene concentrations in our data set are $1.49 \pm 1.74$ and $0.80 \mu \mathrm{g} \mathrm{m}^{-3}$, respectively. These values are lower than standards in both TAQR and the standard given in EU Directive 2008/50/EC (European Commission, 2008).

\subsection{Factor Analysis}

Application of factor analysis revealed nine VOC sources in METU campus. Factor 1 is found as exhaust emissions from gasoline vehicles. It is heavily weighted by ethylene, propane, isobutane, 1-butene, isopentane, benzene, ethylbenzene, $\mathrm{m}, \mathrm{p}$ - xylene and o-xylene. These are all good markers for traffic emissions (Kota et al., 2014; Song et al., 2008; Yu et al., 2014). Absence of combustion products such as acethylene and isopentane promotes this result. 
Table 1. Descriptive Statistics of the Collected Data $\left(\mu \mathrm{g} \mathrm{m}^{-3}\right)$

\begin{tabular}{|c|c|c|c|c|c|}
\hline & MDL & Minimum & Maximum & Median & Mean \\
\hline Ethane & 0.019 & 0.0321 & 21.71 & 3.56 & $4.59 \pm 3.49$ \\
\hline Ethylene & 0.046 & 0.1416 & 51.12 & 5.28 & $8.13 \pm 8.16$ \\
\hline Propane & 0.082 & 0.0775 & 11.57 & 0.99 & $1.69 \pm 1.89$ \\
\hline Propylene & 0.050 & 0.1351 & 23.43 & 2.38 & $3.57 \pm 3.47$ \\
\hline Isobutane & 0.097 & 0.2976 & 54.90 & 6.14 & $9.35 \pm 9.25$ \\
\hline Acethylene & 0.049 & 0.0006 & 16.31 & 0.60 & $1.21 \pm 1.82$ \\
\hline Trans - 2 - Butene & 0.074 & 0.0007 & 1.37 & 0.30 & $0.36 \pm 0.27$ \\
\hline 1 - Butene & 0.064 & 0.0285 & 1.58 & 0.21 & $0.30 \pm 0.28$ \\
\hline Cis-2-Butene & 0.016 & 0.0024 & 83.60 & 4.12 & $5.71 \pm 7.61$ \\
\hline Cyclopentane & 0.105 & 0.0194 & 0.64 & 0.16 & $0.19 \pm 0.12$ \\
\hline Isopentane & 0.170 & 0.0900 & 20.12 & 2.91 & $3.69 \pm 3.01$ \\
\hline n - Pentane & 0.115 & 0.0522 & 49.28 & 0.57 & $0.99 \pm 3.40$ \\
\hline Trans - 2 - Pentene & 0.111 & 0.0033 & 1.18 & 0.04 & $0.06 \pm 0.10$ \\
\hline 1 - Pentene & 0.123 & 0.0051 & 0.93 & 0.11 & $0.14 \pm 0.11$ \\
\hline Cis-2- Pentene & 0.146 & 0.0021 & 0.30 & 0.03 & $0.04 \pm 0.06$ \\
\hline 2,2-Dimethylbutane & 0.146 & 0.0005 & 2.78 & 0.39 & $0.50 \pm 0.41$ \\
\hline 2.3-Dimethylbutane & 0.143 & 0.0029 & 3.15 & 0.34 & $0.40 \pm 0.35$ \\
\hline 2-Methylpentane & 0.145 & 0.0294 & 17.39 & 0.92 & $1.27 \pm 1.47$ \\
\hline 3-Methylpentane & 0.161 & 0.0066 & 4.10 & 0.52 & $0.65 \pm 0.56$ \\
\hline Isoprene & 0.157 & 0.0109 & 25.70 & 0.35 & $0.59 \pm 1.78$ \\
\hline n-Hexane & 0.138 & 0.0038 & 54.89 & 1.86 & $3.32 \pm 5.61$ \\
\hline 2.4-Dimethylpentane & 0.094 & 0.0030 & 2.69 & 0.13 & $0.18 \pm 0.23$ \\
\hline Benzene & 0.093 & 0.0283 & 13.22 & 0.80 & $1.49 \pm 1.74$ \\
\hline Cyclohexane & 0.069 & 0.0006 & 1.46 & 0.11 & $0.18 \pm 0.21$ \\
\hline 2-Methylhexane & 0.109 & 0.0019 & 1.64 & 0.15 & $0.26 \pm 0.29$ \\
\hline 2.3-Dimethylpentane & 0.212 & 0.0009 & 2.43 & 0.15 & $0.23 \pm 0.28$ \\
\hline 3-Methylhexane & 0.089 & 0.0150 & 3.39 & 0.66 & $0.85 \pm 0.68$ \\
\hline 2.2.4-Trimethylpentane & 0.099 & 0.0005 & 3.43 & 0.41 & $0.64 \pm 0.67$ \\
\hline n-Heptane & 0.073 & 0.0050 & 12.58 & 0.22 & $0.45 \pm 1.01$ \\
\hline Methylcyclohexane & 0.120 & 0.0031 & 2.63 & 0.08 & $0.17 \pm 0.32$ \\
\hline 2.3.4-Trimethylpentane & 0.047 & 0.0028 & 2.74 & 0.05 & $0.26 \pm 0.57$ \\
\hline Toluene & 0.088 & 0.5070 & 88.71 & 5.84 & $10.30 \pm 13.84$ \\
\hline 2-Methylheptane & 0.133 & 0.0018 & 3.34 & 0.33 & $0.46 \pm 0.46$ \\
\hline 3-Methylheptane & 0.098 & 0.0014 & 0.99 & 0.07 & $0.11 \pm 0.15$ \\
\hline n-Octane & 0.117 & 0.0018 & 1.61 & 0.13 & $0.21 \pm 0.23$ \\
\hline Ethylbenzene & 0.089 & 0.0067 & 5.71 & 0.50 & $0.76 \pm 0.87$ \\
\hline p-Xylene & 0.122 & 0.0144 & 9.09 & 0.71 & $1.24 \pm 1.46$ \\
\hline Styrene & $0.051^{*}$ & 0.0065 & 12.08 & 0.29 & $0.71 \pm 1.28$ \\
\hline o-Xylene & 0.102 & 0.0038 & 12.72 & 0.58 & $0.99 \pm 1.32$ \\
\hline Nonane & 0.091 & 0.0001 & 2.48 & 0.16 & $0.29 \pm 0.35$ \\
\hline Isopropylbenzene & 0.074 & 0.0016 & 3.40 & 0.08 & $0.18 \pm 0.39$ \\
\hline n-Propylbenzene & $0.029^{*}$ & 0.0047 & 9.31 & 0.11 & $0.28 \pm 0.81$ \\
\hline m-Ethyltoluene & $0.073^{*}$ & 0.0027 & 1.62 & 0.21 & $0.31 \pm 0.31$ \\
\hline 1.3.5-Trimethylbenzene & $0.073^{*}$ & 0.0096 & 3.84 & 0.57 & $0.77 \pm 0.71$ \\
\hline o-Ethyltoluene & 0.538 & 0.0037 & 5.81 & 0.13 & $0.40 \pm 0.79$ \\
\hline 1.2.4-Trimethylbenzene & 0.094 & 0.0019 & 5.45 & 0.54 & $1.10 \pm 1.30$ \\
\hline n-Decane & 0.137 & 0.0017 & 5.01 & 0.48 & $0.84 \pm 1.08$ \\
\hline 1.2.3-Trimethylbenzene & 0.089 & 0.0709 & 15.71 & 2.14 & $3.09 \pm 2.99$ \\
\hline p-Diethylbenzene & 0.115 & 0.0092 & 7.55 & 0.64 & $1.24 \pm 1.51$ \\
\hline n-Undecane & 0.110 & 0.0103 & 54.78 & 1.63 & $3.33 \pm 6.12$ \\
\hline n-Dodecane & 0.106 & 0.0021 & 116.79 & 5.56 & $7.76 \pm 11.11$ \\
\hline
\end{tabular}

Presence of propane and isobutane also suggests that LPG fuel exhaust emissions is merged into Factor 1 as they are also the good markers of LPG emissions (Kuntasal, 2005;
Yurdakul, 2014). Factor 1 accounts for approximately 35\% of the system variance, which makes this factor by far the 
most important source of VOCs measured in Ankara atmosphere.

Factor 2 is heavily loaded with isopentane, 2,2Dimethylbutane, 2,3-Dimethylbutane, 2-Methylpentane, 2,4-Dimethylpentane and cyclohexane. Methylated butanes (Kota et al., 2014), isopentane (Kota et al., 2014) and cyclohexane (McCarthy et al., 2013) are tracers for evaporative emissions from vehicles. Monthly variations of Factor 1 and Factor 2 scores are quite similar with similar variation in winter and summer. Although an increase is expected in summer for evaporative sources, it is not valid for evaporative emissions from vehicles as it is dependent on engine temperature rather than ambient temperature. Factor 2 accounts for approximately $12 \%$ of the system variance. Although its contribution is not as high as Factor
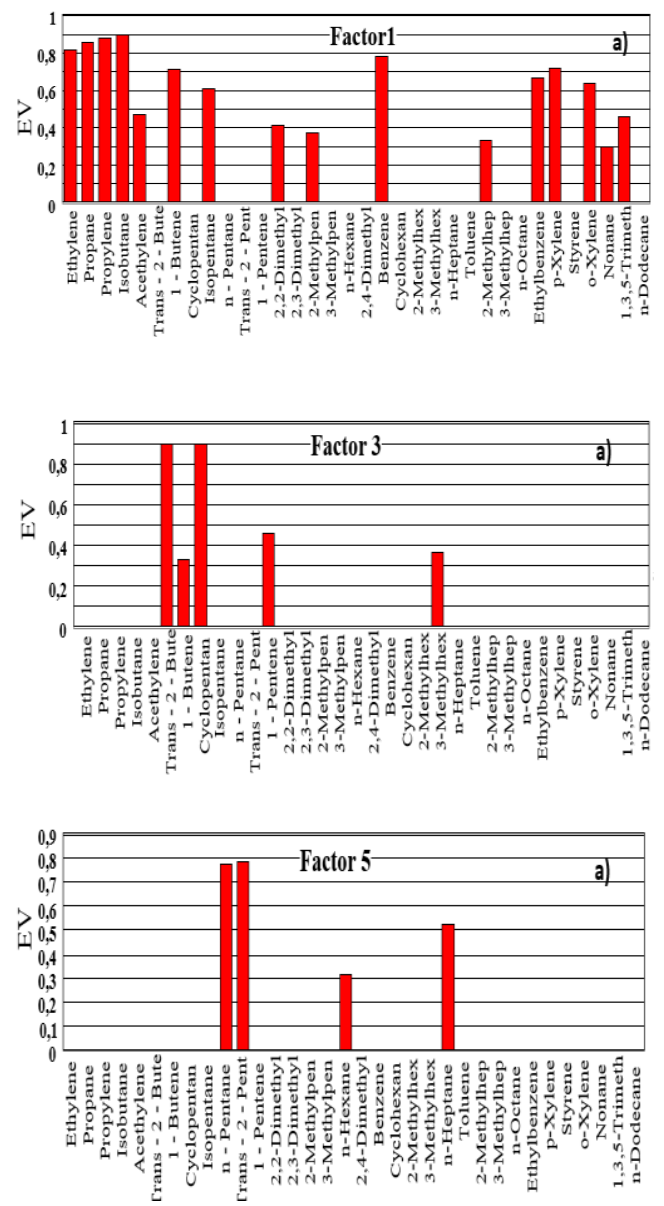

1, Factor 2 is an important source of VOCs in suburban Ankara atmosphere.

Factor 3 is heavily loaded by trans-2-butene, cyclopentane and 1-pentene with reasonable loadings of 1-butene and 3methylhexane. Butane, various pentanes and methylated pentanes are clearly associated with fuel evaporation by McCarthy et al., (2013). Liu et al., (2008) showed that methylated pentanes and butane are highly enriched in gasoline headspace samples. Based on these arguments, Factor 3 is recognized as gasoline evaporation in gas stations. Monthly variation of factor scores also showed a temperature dependent pattern with an increase in summer months. This factor explained $7 \%$ of the system variance.
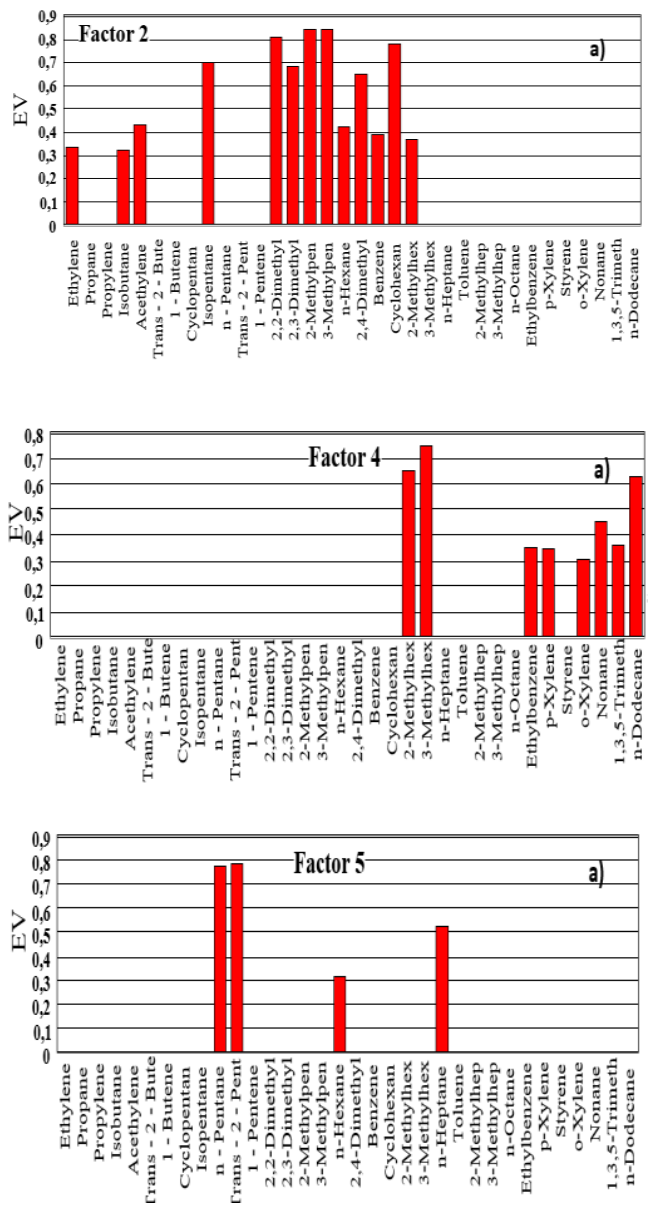

Figure 2. Factor loadings for Factors 1-6

Factor 4 is heavily loaded with 2-methylhexane, 3methylhexane, n-dodecane with loadings of BTEX compounds and nonane. This is a typical diesel factor as diesel emissions are characterized by heavy hydrocarbons, including undecane, decane, dodecane (Ho et al., 2009; McCarthy et al., 2013; Song et al., 2008b). Particularly dodecane is a good tracer for diesel emissions (McCarthy et al., 2013; Schauer et al., 1996; Uzunpınar, 2015). Monthly variations of factor scores are higher in summer compared to winter and this indicates that diesel emission sources contribute to VOC emissions more during summer months. Factor 4 explained $6 \%$ of the system variance.
Factor 5 is heavily loaded with $n$ - pentane and trans-2pentene. It also has moderate loadings of $n$-heptane and $n$ hexane. These compounds are associated with industrial evaporations in most FA studies (Kota et al., 2014; McCarthy et al., 2013) as they are used in a number of industrial applications. Therefore, Factor 5 is identified as industrial evaporation factor. Monthly variation of factor scores shows similar pattern between summer and winter with a slight increase during summer months. This is consistent with industrial evaporations as industrial applications do not vary significantly between summer and winter. Factor 5 explained $5 \%$ of the system variance. 
Factor 6 is loaded with toluene, 2-methylheptane and 3methylheptane. Toluene is an indicator of gasoline exhaust. But, it is also a good marker for evaporative emissions, particularly from paint applications (Liu et al., 2005; Zhang et al., 2011). Additionally, 3-methylheptane and toluene are associated with coatings in buildings and paint by Yu et al., (2014). Monthly factor scores are high both in summer and in winter. High scores in summer season is probably due to increased emissions owing to high temperatures in summer (Uzunpınar, 2015). Factor 6 is identified as surface coatings in buildings and emissions from paint applications and accounts for $6 \%$ of the system variance.

Last three factors explain $9.7 \%$ of the whole system variable altogether. These sources are found to be asphalt application, another solvent use and styrene weighted applications, which was also attributed to industrial applications (Uzunpınar, 2015)

\section{Conclusions}

In this study, 55 PAMS VOCs were measured in suburban Ankara atmosphere in order to determine the concentrations of these compounds and their major sources. Median concentrations ranged between $0.03-6.14 \mathrm{\mu g} \mathrm{m}^{-3}$ for cis-2-pentene and isobutene, whereas mean concentrations ranged between $0.04 \pm 0.06$ and $10.30 \pm 13.84$ for cis-2-pentene and toluene, respectively.

Application of factor analysis revealed nine VOC sources which explained almost $80 \%$ of the system variance in total. These sources can be grouped into four as (1) transportation: gasoline vehicle exhaust emissions (Factor 1: 35\%), evaporative losses from gasoline vehicles (Factor 2: 12\%), gasoline evaporation in gas stations (Factor 3: 7\%) and diesel emissions (Factor 4: 6\%), (2) industrial emissions: industrial evaporation (Factor 5: 5\%) and industrial application (Factor 9), (3) solvent emissions: surface coatings (Factor 6: 6\%) and second solvent use (Factor 8) and (4) asphalt application (Factor 7: 3.5\%). Last three factors, Factor 7, 8 and 9, accounted $9.7 \%$ of the total system variance. As transportation, or the emissions from vehicles and due to vehicle use, covers $60 \%$ of the system variance, it is found to be the major source of VOCs at METU campus.

\section{Acknowledgements}

We thank TUBITAK (The Scientific and Technical Research Council of Turkey), Project no. 112Y036, for the financial support.

\section{References}

Atkinson R. and Arey J. (2003), Gas-phase tropospheric chemistry of biogenic volatile organic compounds: a review. Atmospheric Environment, 37(2), 197-219. doi:10.1016/S1352-2310(03)00391-1

Civan M.Y., Kuntasal Ö.O. and Tuncel G. (2011), Source Apportionment of Ambient Volatile Organic Compounds in Bursa, a Heavily Industrialized City in Turkey, Environmental Forensics, 12(4), 357-370. doi:10.1080/15275922.2011.622345
EDGAR. (2011). EDGAR - Emission Database for Global Atmospheric Research. Global Emissions EDGAR v4.2 (November 2011). Retrieved June 21, 2015, from http://edgar.jrc.ec.europa.eu/overview.php?v=42

European Commission. (2008). DIRECTIVE 2008/50/EC OF THE EUROPEAN PARLIAMENT AND OF THE COUNCIL of 21 May 2008 on ambient air quality and cleaner air for Europe. Retrieved June 26, 2014, from http://eur-lex.europa.eu/legalcontent/EN/TXT/PDF/?uri=CELEX:32008L0050\&from=EN

Han X. and Naeher L P. (2006), A review of traffic-related air pollution exposure assessment studies in the developing world, Environment International, 32(1), 106-20, doi:10.1016/j.envint.2005.05.020

Ho K.F., Lee S.C., Ho W.K., Blake D.R., Cheng Y., Li Y.S., Ho S.S.H., Fung K., Louie P.K.K. and Park D. (2009), Vehicular emission of volatile organic compounds (VOCs) from a tunnel study in Hong Kong, Atmospheric Chemistry and Physics, 9(19), 7491-7504. doi:10.5194/acp-9-7491-2009

Kota S.H., Park C., Hale M.C., Werner N.D., Schade G.W. and Ying Q. (2014), Estimation of VOC emission factors from flux measurements using a receptor model and footprint analysis, Atmospheric Environment, 82, 24-35. doi:10.1016/j.atmosenv.2013.09.052

Kountouriotis A., Aleiferis P.G. and Charalambides A.G. (2014), Numerical investigation of VOC levels in the area of petrol stations, The Science of the Total Environment, 470-471, 1205-1224. doi:10.1016/j.scitotenv.2013.10.064

Kuntasal Ö.O. (2005), Temporal Variations and Sources of Organic Pollutants in Two Urban Atmospheres: Ankara and Ottawa. Middle East Technical University.

Liu C.-C., Chen W.-H., Yuan C.-S. and Lin C. (2014), Multivariate analysis of effects of diurnal temperature and seasonal humidity variations by tropical savanna climate on the emissions of anthropogenic volatile organic compounds, The Science of the Total Environment, 470-471, 311-323. doi:10.1016/j.scitotenv.2013.09.102

Liu J., Li N., Jiang G., Liu J., Jönsson J.Å. and Wen M. (2005), Disposable ionic liquid coating for headspace solid-phase microextraction of benzene, toluene, ethylbenzene, and xylenes in paints followed by gas chromatography-flame ionization detection, Journal of Chromatography A, 1066(1-2), 27-32. doi:10.1016/j.chroma.2005.01.024

McCarthy M.C., Aklilu Y.-A., Brown S.G. and Lyder D.A. (2013), Source apportionment of volatile organic compounds measured in Edmonton, Alberta, Atmospheric Environment, 81, 504-516. doi:10.1016/j.atmosenv.2013.09.016

MGM. (2014). T.C. Orman ve Su İşleri Bakanlığı Meteoroloji Genel Müdürlüğü - Resmi İstatistikler. Retrieved July 27, 2015, from http://www.mgm.gov.tr/veridegerlendirme/il-ve-ilceleristatistik.aspx

MoEU. (2008). Hava Kalitesi Değerlendirme ve Yönetimi Yönetmeliği. Ankara. Retrieved from http://www.csb.gov.tr/gm/cygm/index.php?Sayfa=sayfa\&Tu $r=$ webmenu\& $\mid d=266$

Rourke N.O. and Hatcher L. (2013). Factor Analysis and Structural Equation Modeling Second Edition (2nd ed.). North Carolina: SAS Institute Inc. Retrieved from http://support.sas.com/publishing/pubcat/chaps/61314.pdf

Schauer J.J., Rogge W.F., Hildemann L.M., Mazurek M.A., Cass G.R. and Simoneit B.R.T. (1996), Source apportionment of airborne particulate matter using organic compounds as 
tracers, Atmospheric Environment, 30(22), 3837-3855. doi:10.1016/1352-2310(96)00085-4

Song Y., Dai W., Shao M., Liu Y., Lu S., Kuster W. and Goldan P. (2008a), Comparison of receptor models for source apportionment of volatile organic compounds in Beijing , China, 156, 174-183. doi:10.1016/j.envpol.2007.12.014

Song Y., Dai W., Shao M., Liu Y., Lu S., Kuster W. and Goldan P. (2008b), Comparison of receptor models for source apportionment of volatile organic compounds in Beijing, China, Environmental Pollution (Barking, Essex : 1987), 156(1), 174-83. doi:10.1016/j.envpol.2007.12.014

Turkish Statistical Institute. (2014). General Census 2000. Nüfus İstatistikleri. Retrieved May 11, 2015, from http://www.tuik.gov.tr/UstMenu.do?metod=temelist

U.S.EPA. (1999). Compendium of Methods for the Determination of Toxic Organic Compounds in Ambient Air Second Edition Compendium Method TO-15 Determination Of Volatile Organic Compounds ( VOCs ) In Air Collected In SpeciallyPrepared Canisters And Analyzed By Gas Chromato.

U.S.EPA. (2009). Definition of Volatile Organic Compounds (VOC). Retrieved June 15, 2015, from http://www.epa.gov/ttn/naaqs/ozone/ozonetech/def_voc.h tm

Uzunpınar, E. S. (2015). Source Apportionment of Volatile Organic Compounds in Ankara Atmosphere. Middle East technical University. Retrieved from http://library.metu.edu.tr/search/a?SEARCH=uzunpınar

Wang D.K.W. and Austin C.C. (2006), Determination of complex mixtures of volatile organic compounds in ambient air: an overview, Analytical and Bioanalytical Chemistry, 386(4), 1089-1098. doi:10.1007/s00216-006-0475-5

WHO. (2015). Air Pollution. Retrieved February 16, 2015, from http://www.who.int/topics/air_pollution/en/

Williams J. and Koppmann R. (2007), Volatile Organic Compounds in the Atmosphere: An Overview. In R. Koppman (Ed.), Volatile Organic Compounds in the Atmosphere (1st ed.). Blackwell Publishing.

Yu C.H., Zhu X. and Fan Z. (2014), Spatial/temporal variations and source apportionment of VOCs monitored at community scale in an urban area, PloS One, 9(4), e95734. doi:10.1371/journal.pone.0095734

Yurdakul S. (2014). Temporal Variation of Volatile Organic Compound Concentrations in Bursa Atmosphere. Middle East Technical University. Retrieved from http://library.metu.edu.tr/search S15?/ayurdakul/ayurdakul /1,13,13,B/l856 b1967864\&FF=ayurdakul+sema\&1,1,1,0

Zemankova K. and Brechler J. (2010), Emissions of biogenic VOC from forest ecosystems in central Europe: estimation and comparison with anthropogenic emission inventory, Environmental Pollution (Barking, Essex: 1987), 158(2), 462-469. doi:10.1016/j.envpol.2009.08.032

Zhang S., Zhao T., Wang H. and Wang J. (2011), Comparison of SPE-TD-GC-FID with UPLC-PDA and GC-MS Methods for Analysis of Benzene, Toluene and Xylene Isomers in SolidLiquid Mixing Paints, Chromatographia, 74(1-2), 163-169. doi:10.1007/s10337-011-2029-z 